\title{
EFEKTIVITAS PROGRAM ME'DASENG DI KECAMATAN TABUKAN UTARA, KABUPATEN KEPULAUAN SANGIHE
}

\section{EFFECTIVITY OF ME'DASENG PROGRAM IN NORTH TABUKAN SUB-DISTRICT, SANGIHE ISLAND REGENCY}

\section{Yerry Efendi Budiman ${ }^{(1)}$, Daud Markus Liando ${ }^{(2)}$, Donald K. Monintja ${ }^{(2)}$}

\author{
1) Peneliti Independen \\ 2) Staf Pengajar dan Peneliti pada Prodi Pengelolaan Sumberdaya Pembangunan Program Pascasarajana, \\ Universitas Sam Ratulangi, Manado \\ *Penulis untuk korespondensi: yerrybudiman@yahoo.com
}

\begin{tabular}{ll}
\hline Naskah diterima Redaksi Jurnal Ilmiah Agrisosioekonomi & : Jumat, 15 Januari 2021 \\
Disetujui diterbitkan & : Jumat, 29 Januari 2021 \\
\hline
\end{tabular}

\begin{abstract}
This study aims to describe the effectiveness of the Me'Daseng program. Measurement of effectiveness used four elements in accordance with Budiani (2009) concept namely: the accuracy of target, socialization, objectives, and monitoring. The research was conducted in the North Tabukan Sub-district, Sangihe Islands Regency. The selection of informants was carried out purposively with a total of 12 informants. The data used are primary and secondary data. Primary data were collected by conducting interviews with informants and making direct observations. Secondary data were collected by conducting literature studies and searching online data related to the theme of this research, namely program effectiveness. The data analysis technique used descriptive qualitative data analysis techniques. The results showed that (1) the Me'Daseng program was not yet fully effective, in terms of target accuracy. The community was still less involved or served when the Me'Daseng program was implemented. (2) Socialization of the Me'Daseng program has been carried out, but it has not been very good, especially the direct socialization carried out in communities. (3) The effectiveness of the Me'Daseng program when viewed from the objectives of the Me'Daseng program and compared to the results achieved, has not been very effective. (4) The government has made efforts to make improvements in the implementation of the Me'Daseng program, as an effort to pay attention to the community receiving services from the Me'Daseng program, but the impact felt by the community is still not as expected.
\end{abstract}

Keywords: program effectiveness, the accuracy of target, socialization, objectives, monitoring

\section{ABSTRAK}

Penelitian ini bertujuan untuk mendeskripsikan efektivitas dari program Me'Daseng. Pengukuran efektivitas menggunakan empat unsur sesuai dengan pemikiran Budiani (2009) yaitu: ketepatan sasaran, sosialisasi, tujuan, pemantauan. Penelitian dilakukan di Kecamatan Tabukan Utara, Kabupaten Kepulauan Sangihe. Pemilihan informan dilakukan secara sengaja sebanyak 12 orang. Data yang digunakan berupa data primer dan sekunder. Data primer dikumpulkan dengan melakukan wawancara pada informan dan melakukan pengamatan secara langsung. Data sekunder dikumpulkan dengan melakukan studi kepustakaan dan penelusuran data online yang berkaitan dengan thema penelitian ini yaitu efektivitas program. Teknik Analisa data menggunakan teknik analisis data deskriptif kualitatif. Hasil penelitian menunjukkan bahwa (1) Program Me’Daseng di Kecamatan Tabukan Utara belum sepenuhnya efektif, dari segi ketepatan sasaran. Masyarakat masih kurang terlibat atau terlayani disaat dilaksanakannya program Me'Daseng. (2) Sosialsiasi program Me'Daseng sudah dilakukan, namun belum begitu baik terutama sosialisasi langsung yang dilakukan di masyarakat yang ada di Kecamatan Tabukan Utara. (3) Efektivitas program Me'Daseng di Kecamatan Tabukan Utara jika dilihat dari tujuan program Me'Daseng dan dibandingkan dengan hasil yang dicapai belum begitu efektif. (4) Pemerintah sudah berupaya melakukan perbaikan dalam penyelenggaraan program Me'Daseng, sebagai upaya untuk memperhatikan masyarakat penerima pelayanan dari program Me'Daseng, tetapi dampak yang dirasakan oleh masyarakat masih belum sesuai yang diharapkan.

Kata kunci: efektifitas program, ketepatan sasaran, sosialisasi, tujuan, pemantauan 


\section{PENDAHULUAN}

\section{Latar Belakang}

Kabupaten Kepulauan Sangihe merupakan sebuah daerah kepulauan di Provinsi Sulawesi Utara, Indonesia yang berbatasan lansung dengan Negara Filipina. Dalam melaksanakan tugas dan fungsinya pemerintah daerah Kabupaten Kepulauan Sangihe ingin membangun lebih baik lagi daerah tersebut mengingat Kabupaten Sangihe merupakan salah satu daerah perbatasan diwilayah Negara Kesatuan Republik Indonesia (NKRI). Pemerintah Daerah yaitu kepala daerah sebagai unsur penyelenggara Pemerintahan Daerah yang memimpin pelaksanaan urusan pemerintahan yang menjadi kewenangan daerah otonom.

Dalam rangka menindaklanjuti deklarasi "Service Power For Sangihe" yang telah dicanangkan oleh Bupati Kepulauan Sangihe. Juga sebagai komitmen untuk melaksanakan pelayanan masyarakat semaksimal mungkin, dan dalam rangka perbaikan tata pemerintahan yang mendorong pemahaman tentang betapa pentingnya suatu kualitas pelayanan publik serta perbaikan mutu pelayanan publik maka deklarasi dimaksud harus mampu dijabarkan dalam pelaksanan tugas pelayanan publik sebagai tugas pokok Pemerintah Daerah. Dengan menimbang tuntutan masyarakat terhadap proses, jarak, waktu, dan biaya yang dikeluarkan untuk memeperoleh dan atau menjangkau pelayanan, serta keinginan tentang adanya sosok pemimpin yang dekat dengan rakyat. Dari konsep dimaksud (Service Power For Sangihe), telah melahirkan sebuah program inovatif yang mana intinya untuk melaksanakan tugas pelayanan optimal dan efisien serta mendekatkan diri dengan masyarakat. Program yang dimaksud yaitu "Me'Daseng", dengan tajuk kunjungan kerja Bupati dan Wakil Bupati ke-wilayah.

Me'Daseng merupakan nama program kunjungan kerja wilayah Bupati, Wakil Bupati bersama perangkat daerah Kabupaten Kepulauan Sangihe, juga melibatkan forkopimda, dan instansi-instansi lainya yang berkaitan dengan pelayanan publik. Melalui program Me'Daseng ini juga pemerintah berupaya membangun pemerintah yang melayani rakyat, handal, dengan tata kelola yang efektif, akuntabel, dijalankan aparatur penyelenggara berintegritas, profesional, bebas korupsi, kolusi, dan nepotisme sehingga pemerintah daerah melaksanakan pelayanan langsung diwilayah dan berbagai kegiatan untuk menjawab kebutuhan rakyat, menyerap aspirasi masyarakat dan menginap dirumah warga.

Program Me'Daseng ini menjadi program unggulan di Kabupaten Kepulauan Sangihe. Melalui program Me'Daseng ini diharapakan mampu mengatasi permasalahan pelayanan publik yang ada di Kabupaten Kepulauan Sangihe melalui tiap kecamatan. Namun, pelaksanaannya belum sesuai harapan masyarakat, hal ini dapat dibuktikan dengan belum secara menyeluruh masyarakat di Kecamatan Tabukan Utara dapat merasakan pelayanan dari Satuan Kerja Pemerintah Daerah (SKPD) terkait.

Program Me'Daseng diselenggarakan disemua kecamatan se-Kabupaten Kepulauan Sangihe secara terjadwal dan bergantian. Secara teknis Me'Daseng di koordinir oleh Bagian Pemerintahan dan Otonomi Daerah Setda Kabupaten Kepulauan Sangihe. Suatu Program kebijakan bertujuan untuk mensejahterakan masyarakat, termasuk dengan adanya program Me'Daseng maka masyarakat seharusnya juga bisa merasakan keuntungan, kebijakan ini diharapkan dapat mendorong agar memberikan pelayanan terbaik untuk masyarakat, harapan dilaksanakannya program ini hanya mestinya dapat memberikan kesempatan kepada masyarakat untuk menyampaikan aspirasi dan permasalahan kepada pemerintah, membangun pemerintahan yang melayani serta peduli terhadap permasalahan dan aspirasi masyarakat, meningkatkan hubungan kerja sama antara pemerintah, masyarakat dan dunia usaha, dan memberikan kemudahan, kecepatan, keterjangkauan, keamanan, dan kenyamanan kepada masyarakat dalam mendapatkan pelayanan, mengembangkan nilai-nilai adat istiadat masyarakat Sangihe. Namun, dalam pelaksanaanya masih jauh dari harapan masyarakat.

Program ini dibentuk berdasarkan komitmen pemerintah daerah untuk penjabaran Visi dan Misi Kabupaten Kepulauan Sangihe dan Surat Keputusan Bupati Kabupaten Kepulauan Sangihe Nomor 172.1/710/Tahun 2017 Tentang Penetapan Wilayah/ Lokasi Pelaksanaan Program Me'Daseng di Lingkungan Pemerintahan Kabupaten Kepulauan Sangihe. Dalam pelaksanaannya Program ini terjadwal selama 5 (lima) hari ditiap kecamatan dan diselenggarakan secara bergantian disemua kecamatan seKabupaten Kepulauan Sangihe secara bergantian, idealnya pada hari selasa sampai hari sabtu. Pada 
hari Selasa sampai hari Kamis yaitu jadwal kegiatan SKPD untuk melakukan kegiatan pelayanan langsung diwilayah. Kegiatan yang dilakukan meliputi : Sosialisasi, Penyuluhan, Pendataan, Pelayanan Administrasi, Pelayanan Perijinan, Pemeriksaan Kesehatan dan Pengobatan gratis. Sedangkan pada hari jumat, dilaksanakan tatap muka Pimpinan Daerah bersama perangkat daerah, forkopimda, serta seluruh elemen masyarakat setempat. Dalam kegiatan yang dimaksud, diagendakan Forum Me'Sombang yang artinya "Bertemu", masyarakat bertemu secara langsung dengan pimpinan daerah.

Pada saat dilkukan observasi awal ditemukan hal yang menarik juga menjadi fenomena yaitu Program Me'Daseng ini hanya dilaksanakan dalam waktu 2 (dua) hari ditiap kecamatan yaitu pada hari jumat dan sabtu. Kegiatan pelayanan hanya dilakukan 1 (satu) hari saja sehingga belum semua masyarakat di Kecamatan Tabukan Utara mendapatkan pelayanan. Hal ini mengakibatkan pelayanan yang dilakukan kurang maksimal. Di hari terakhir dilaksanakan tatap muka antara pemerintah daerah dan masyarakat untuk menyerap aspirasi masyarakat. Kegiatan tatap muka ini juga hanya mendengarkan keluhan masyarakat saja belum ada tindakan lanjut dari SKPD terkait. Hal ini jelas mengindikasikan bahwa dari pelaksanaan program ini belum sesuai harapan dari masyarakat. Dan yang menjadi alasan tidak dilaksanakan sesuai jadwal yang ditentukan yaitu, anggran yang belum mencukupi dan keterbatasan jumlah Aparatur Sipil Negara (ASN).

Berdasarkan uraian yang telah dikemukakan maka penulis tertarik untuk meneliti dan membahas mengenai "Efektivitas Program Me'Daseng di Kecamatan Tabukan Utara, Kabupaten Kepulauan Sangihe”. Banyak peneliti terdahulu yang telah melaksanakan penelitian semacam ini seperti pada Dewi Puji Lestari Mahasiswa Administrasi Publik Universitas Negeri Surabaya (2018), Afrisa Farchan Dwi Putra Mahasiswa Hukum dan Kewarganegaraan Universitas Negeri Malang (2017), Anita Nurak Mahasiswa Ilmu Pemerintahan Universitas Hasanudin (2010), Sukmaniar Mahasiswa Teknik Pembangunan Wilayah dan Kota Universitas Diponegoro (2007). Tetapi yang membedakan penelitian ini dengan penelitian terdahulu yaitu cara pemberdayaannya yang menggambarkan kearifan lokal masyarakat yang ada di Kabupaten Kepulauan Sangihe.

\section{Rumusan Masalah}

Berdasarkan latar belakang masalah yang telah diuraikan maka yang menjadi rumusan masalah dalam penelitian ini adalah apakah program Me'Daseng di Kecamatan Tabukan Utara, Kabupaten Kepulauan Sangihe sudah berjalan dengan baik?

\section{Tujuan Penelitian}

Penelitian ini bertujuan untuk mengetahui mengenai efektivitas program Me'Daseng di Kecamatan Tabukan Utara, Kabupaten Kepulauan Sangihe.

\section{Manfaat Penelitian} manfaat:

Diharapkan penelitian ini memberikan

1. Manfaat Akademis

Hasil penelitian ini diharapkan bermanfaat sebagai referensi dalam pengembangan pengembangan Ilmu Pengetahuan khususnya Ilmu Pemerintahan dan sebagai bahan masukan atau referensi untuk penelitian berikutnya.

2. Manfaat Praktis

Hasil penelitian ini diharapkan bermanfaat sebagai masukan dan informasi kepada Pemerintah serta memberikan kontribusi positif terhadap efektivitas dari sebuah program yang dibuat oleh pemerintahan.

3. Manfaat Teknis

a) Sebagai sumbangan pemikiran dan sebagai masukan serta perbaikan dalam pelaksanaan program agar lebih efektif sehingga program Me'Daseng lebih berdaya guna bagi masyarakat.

b) Untuk Pemerintah Kepulauan Sangihe, diharapakan penelitian ini dapat digunakan sebagai bahan pelaksanaan sebuah kebijakan agar lebih efektif sehingga dapat memberikan manfaat kepada masyarakat.

\section{METODE PENELITIAN}

\section{Desain Penelitian}

Dalam penelitian ini peneliti menggunakan desain kualitatif, yaitu suatu penelitian kontekstual yang menjadikan manusia sebagai instrument, dan disesuiakan dengan situasi yang wajar dalam kaitanya dengan pengumpulan data 
yang pada umumnya bersifat kualitatif. Pendekatan kualitatif dicirikan oleh tujuan penelitian yang berupaya memahami gejalagejala yang sedemikian rupa yang tidak memerlukan kuantifikasi, karena gejala tidak memungkinkan untuk diukur secara tepat.

Penelitian ini mendeskripsikan efektivitas dari program Me'Daseng sehingga penelitian dilakukan di Kabupaten Kepulauan Sangihe dengan lokasi penelitian yaitu Kantor Pemerintah Daerah Kabupaten Sangihe dan Kantor Kecamatan Tabukan Utara serta yang menjadi informan yaitu stakeholder dan yang mungkin dapat memberikan data dalam penelitian yaitu : Bupati Kabupaten Kepulauan Sangihe, Camat Tabukan Utara, dan masyarakat.

Untuk dapat mengetahui dan menggambarkan apakah program Me'Daseng di Kecamatan Tabukan Utara, Kabupaten Kepulauan Sangihe sudah berjalan dengan baik atau tidak, maka diperlukan suatu aktivitas penelitian sebagai serangkaian kegiatan mengumpulkan, menggambarkan dan menafsirkan data tentang situasi yang dialami, kegiatan, hubungan tertentu, pandangan atau sikap yang ditunjukan atau tentang kecenderungan yang tampak dalam proses yang sedang berlangsung.

\section{Fokus Penelitian}

Batasan masalah dalam penelitian kualitatif disebut juga dengan fokus yang berisi pokok masalah yang bersifat umum. Dengan demikian dalam penelitian kualitatif, hal yang harus diperhatikan adalah masalah dan fokus penelitian, karena untuk memberikan batasan penelitian yang harus diteliti dan mendapatkan data yang sesuai dan dibutuhkan dalam penelitian tersebut.

Fokus dalam penelitian ini adalah efektivitas program Me'Daseng di Kecamatan Tabukan Utara, Kabupaten Kepulauan Sangihe, sesuai dengan teori Budiani (2009) yang menyebutkan beberapa indikator yang digunakan untuk mengukur efektivitas, yaitu:
1. Ketepatan Sasaran
2. Sosialisasi
3. Tujuan
4. Pemantauan

\section{Sumber Data Penelitian}

Sedangkan sumber datanya yaitu :

1) Data primer yaitu data yang diperoleh dari 12 informan dengan wawancara dan pengamatan secara langsung.

2) Data sekunder adalah data yang bersumber dari dokumen-dokumen atau arsip resmi yang berhubungan dengan penelitian.

\section{Metode Analisis Data}

Penelitian ini adalah penelitian deskriptif dengan analisa kualitatif. Metode deskriptif yaitu metode penelitian yang memusatkan perhatian pada masalah ataupun fenomena yang ada pada saat penelitian dilakukan atau pada masalah yang diselidiki sebagaimana adanya diiringi dengan interpretasi yang rasional dan akurat.

\section{Teknik Pengumpulan Data}

Untuk memperoleh data yang akurat, relevan, dan dapat dipertanggung jawabkan maka penulis menggunakan beberapa Teknik dalam pengumpulan data karena masingmasing mempunyai kelebihan dan kekurangan.

Teknik pengumpulan data dalam penelitian ini yaitu:

1. Observasi, yaitu proses pengambilan data dalam penelitian ini dimana peneliti atau pengamat dengan mengamati kondisi yang berkaitan dengan obyek penelitian.

2. Wawancara, adalah percakapan dengan maksud tertentu. Percakapan ini dilakukan oleh dua pihak, yaitu pewawancara (yang mengajukan pertanyaan) dan yang diwawancarai serta memberikan jawaban atas pertanyaan itu. Adapun tahapan-tahapan wawancara meliputi: Menentukan siapa yang diwawancarai, mempersiapkan wawancara, melakukan wawancara dan memelihara agar wawancara produktif, menghentikan wawancara dan memperoleh rangkuman wawancara.

3. Studi Kepustakaan (library research), yaitu dengan membaca buku majalah, surat kabar, dokumen-dokumen, undang-undang, dan media informasi lain yang ada hubungannya dengan Program Me'Daseng.

4. Penelusuran data online, data yang dikumpulkan melalui online seperti internet atau media jaringan lainya yang menyediakan fasilitas secara online sehingga memungkinkan peneliti dapat 
memanfaatkan data-informasi yang berupa data maupun informasi teori, secepat atau semudah mungkin. Dan dapat dipertanggung jawabkan secara akademik.

\section{Teknik Analisa Data}

Teknik Analisa data yang diginakan dalam penelitian ini adalah teknik analisis data deskriptif kualitatif dimana jenis data yang berbentuk informasi baik lisan maupun tulisan yang sifatnya bukan angka. Data dikelompokkan agar lebih mudah dalam menyaring mana data yang dibutuhkan dan mana data yang tidak. Setelah dikelompokkan, data tersebut peneliti jabarkan dengan bentuk teks agar lebih dimengerti. Setelah itu, penulis menarik kesimpulan dari data tersebut, sehingga dapat menjawab pokok masalah penelitian.

Untuk menganalisa berbagai fenomena dilapangan, langkah-langkah yang dilakukan adalah sebagai berikut:

1. Pengumpulan informasi melalui wawancara, observasi langsung dan dokumentasi.

2. Reduksi data, proses pemilihan, perumusan perhatian pada penyederhanaan, transformasi data kasar yang muncul dari catatan lapangan. Langkah ini bertujuan untuk memilih informasi mana yang sesuai dan tidak sesuai dan tidak sesuai dengan masalah peneliti.

3. Penyajian data, setelah data direduksi, langkah analisis selanjutnya adalah penyajian (display) data. Penyajian data diarahkan agar hasil reduksi terorganisasikan, tersusun dalam pola hubungan, sehingga makin mudah dipahami. Penyajian data dapat dilakukan dalam bentuk uraian naratif. Pada langkah ini, peneliti berusaha menyusun data yang relevan, sehingga menjadi informasi yang dapat dilakukan dengan cara menampilkan dan membuat hubungan antar fenomena untuk memaknai apa yang sebenarnya terjadi dan apa yang perlu ditindaklanjuti untuk mencapai tujuan penelitian. Display data yang baik merupakan satu langkah penting menuju tercapainya analisis kualitatif yang valid dan handal.

4. Tahap akhir adalah menarik kesimpulan yang dilakuakn secara cermat dengan melakukan verifikasi berupa tinjauan ulang pada catatancatatan lapangan, sehingga data-data yang ada teruji validasinya.

\section{PEMBAHASAN}

Dalam pembahasan ini akan membahas mengenai analisa data, yaitu data yang diperoleh peneliti melalui wawancara kepada informan. Data harus segera dianalisis setelah dikumpulkan dan dituangkan dalam bentuk laporan dan data dikelompokkan menjadi suatu bagian tertentu menurut data jawaban dari informan. Yang dimaksud analisa data ialah suatu pandangan atau pendapat langsung berdasarkan data dan informan yang didapat dari lapangan dengan berpedoman tetap pada masalah penelitian dan tujuan. Data yang dikumpulkan dari informan yaitu tentang pelaksanaan program Me'Daseng di Kecamatan Tabukan Utara.

Untuk mendapatkan hasil yang baik dan maksimal dalam melaksanakan penelitian, maka perlu diketahuai jawaban dari informan mengenai pelaksanaan program Me'Daseng di Kecamatan Tabukan Utara. Untuk itu peneliti melakukan wawancara kepada informan. Agar data yang diperoleh peneliti nyata yang terjadi pada pelaksanaan program Me'Daseng di Kecamatan Tabukan Utara maka dilakukan wawancara. Sesuai dengan teori yang disebutkan oleh Budiani (2009), ada beberapa indikator yang digunakan untuk mengukur efektivitas yaitu: Ketepatan sasaran program, Sosialisasi program, Tujuan program, Pemantauan program.

\section{Ketepatan Sasaran Program}

Sejauh mana peserta program tepat sasran yang telah ditetapakan sebelumnya. Dalam penelitian ini yang menjadi sasaran program Me'Daseng yaitu masyarakat yang ada di Kecamatan Tabukan Utara. Seperti pada tujuan yang ditetapkan sebelumnya, ada beberapa kegiatan program Me'Daseng yang ditujukan untuk masyarakat. Kegiatan program Me'Daseng diharapkan dapat tepat sasaran program, yaitu kepada masyarakat itu sendiri. Sehingga pada akhirnya diketahui sejauhmana keefektifan program Me'Daseng di Kecamatan Tabukan Utara. Menurut Subagyo dalam Budiani (2009) efektivitas merupakan kesesuaian antara output dengan tujuan yang ditetapkan.

Mecermati ketepatan sasaran program Me'Daseng di Kecamatan Tabukan Utara, Peneliti melakukan wawancara dengan Bupati Kabupaten Kepulauan Sangihe, selaku pembuat program, mengatakan bahwa : 
“Program Me'Daseng yaitu suatu program yang dibuat untuk menangani keluhan masyarakat ditiap kecamatan yang ada di Kabupaten Kepualaun Sangihe yang salah satunya yaitu Kecamatan Tabukan Utara. Apabila dilihat sampai sekarang, program ini berjalan dengan baik dan sesuai sasaran yang telah ditentukan sebelumnya, karena masyarakat langsung yang merasakan dampak dari program Me'Daseng ini."

Pemerintahan Daerah yaitu penyelenggaraan urusan pemerintahan oleh pemerintah daerah dan dewan perwakilan rakyat daerah menurut asas otonomi dan tugas pembantuan dengan prinsip otonomi seluasluasnya dalam sistem dan prinsip Negara Kesatuan Republik Indonesia sebagaimana dimaksud dalam Undang-Undang Dasar Negara Republik Indonesia Tahun 1945. Dan dalam pelaksanaan kewenangan Pemerintah Daerah, melalui SKPD agar dapat melakukan berbagai upaya untuk dapat memberikan pelayanan semaksimal mungkin kepada masyarakat.

Senada dengan pendapat dari Bupati, camat Tabukan Utara juga mengungkapkan bahwa :

"Program Me'Daseng ini sangat tepat sasaran, karena di daerah lain banyak masyarakat yang mengeluhkan pelayanan dari pemerintah, baik dalam pelayanan kesehatan, pembuatan e-KTP dan lain sebagainya. Sedangkan pada program Me'Daseng ini semua SKPD di kerahkan langsung turun ke kecamatan utuk melakukan pelayanan tersebut."

Dalam melaksanakan tugasnya Camat bertanggung jawab memfasilitasi tempat (Daseng) Pelayanan Publik setiap organisasi pemberi layanan, penyampaian informasi kepada masyarakat, tempat Daseng, pelaksanaan kegiatan, pelaporan kegiatan pelayanan, dan evaluasi. Untuk pelaksanaan Me'Daseng, Camat berkoordinasi dengan Asisten Pemerintahan dan Kesra dan Badan Adat Kecamatan dalam menyusun tata tertib pelaksanaan Me'Daseng sesuai dengan adat istiadat di wilayah tersebut.

Pada sisi lain, mengenai ketepatan sasaran program, kepala Desa Beha juga memberikan tanggapan bahwa :

"Jika dilihat dari ketepatan sasaran, progrm Me'Daseng ini belum begitu tepat sasaranya, bisa saja hanya buang-buang anggaran. Belum ada dampak yang begitu efektif di masyarakat. Ada beberapa hal yang harus lebih di tingkatkan dalam pelaksanan program Me'Daseng, salah satunya yaitu waktu pelaksanaan pelayanan yang begitu singkat, baik dalam pelayanan kesehatan, pelayanan e$K T P$, penyuluhan, dan lain-lain ditiap kecamatan, lebih khusus di Kecamatan Tabukan Utara sehingga banyak masyarakat yang mengeluhkan pelayanan."

Penyampaian dari informan kepala Desa Beha juga merupakan keluhan dari masyarakat yang ada mengenai pelayanan yang di berikan SKPD. Pembentukan program Me'Daseng memang banyak di fokuskan pada pelayanan publik di masyarakat, peneliti mencoba untuk menggali informasi tentang pelayanan yang dikeluhkan oleh salah satu Kepala Desa yang ada di Kecamatan Tabukan Utara tersebut dengan melakukan wawancara kepada salah satu dari SKPD terkait yang melaksanakan tugasnya di program Me'Daseng, yang mengatakan bahwa:

"Apa yang kami laksanakan dalam memberi pelayanan kepada masyarakat khususnya yang ada di Kecamatan Tabukan Utara sudah sesuai standar pada umumnya, adakalanya apabila terjadi keterlambatan dalam pelayanan dan juga ada yang belum terlayani baik dalam pembutan e-KTP, ijin usaha, dan lainlain, hanya karena masalah waktu yang singkat untuk pelayanan, seperti yang dikeluhkan kepada kami, hal ini harus di maklumi keterbatasan jumlah ASN pemberi pelayanan yang jumlahnya kurang karena harus berbagi tugas dikantor dan ditempat dilaksanakannya program Me'Daseng itu sendiri."

Berdasarkan hasil wawancara dapat dikatakan bahwa ketepatan sasaran program masih jauh dari yang sudah ditentukan sebelumnya, kurangnya petugas pelayanan dalam pelaksanaan program Me'Daseng menjadi kekurangan dalam hal ketepatan sasaran program.

\section{Sosialisasi Program}

Langkah awal dalam pelaksanaan suatu program yaitu sosialisasi. Sosialisasi mempunyai pengaruh yang sangat besar terhadap suatu program meskipun terlihat ringan dan sepele. Melihat dari kondisi masyarakat yang sangat heterogen baik dilihat dari karakter, pendidikan, 
pemahaman masyarakat dan daya terima, maka dalam proses sosialisasi diharapkan seorang fasilitator harus berhati-hati. Dalam proses sosialisasi seorang fasilitator harus memiliki kemampuan yang komunikatif dalam berkomunikasi. Dikatakan komunikatif tidak diharuskan yang banyak berbicara tetapi pada intinya bagaimana seorang fasilitator dapat menyampaikan informasi dengan tepat, serta bisa dipahami dan diterima oleh masyarakat atau peserta program. Inti dari proses sosialiasai adalah seperti nama program, tujuan, konsep, waktu pelaksanaan, sarana dan target dari program tersebut. Tidak jarang ada masyarakat yang menentang proses pelaksanaan program karena mereka merasa apa yang disampaikan pada saat sosialisasi berbeda dengan yang dilaksanakan.

Ada beberapa metode sosialisasi yang dapat dilakukan antara lain :

1. Sosilisasi langsung, yaitu proses sosialisasi yang dilakukan secara langsung oleh seorang fasilitator kepada masyarakat.

2. Sosialisasi tidak langsung, yaitu melaui perantara. Metode ini efiktif dari segi waktu namun belum menjamin dari segi hasil karena, informasi yang didapat dari masyarakat tidak langsung dari sumbernya.

Sosialisasi juga memiliki fungsi sebagai proses komunikasi kebudayaan kepada masyarakat. Kaitannya dengan penelitian ini "kebudayaan" yaitu program Me'Daseng yang ditujukan kepada masyarakat atau kelompok sasaran program. Dalam penelitian ini sosialisasi mempunyai fungsi sebagai upaya meperkenalkan dan menyebarluaskan informasi mengenai pelaksanaan program Me'Daseng kepada masyarakat yang menjadi sasaran program. Sosialisasi juga merupakan salah satu indikator yang dirumuskan oleh Budiani sebagai syarat untuk mengetauhi tingkat efektivitas dari suatu program. Menurut Budiani (2009) sosialisasi harus dilakukan agar suatu program dapat dipahami secara menyeluruh oleh masyarakat.

Dari hasil penelitian diperoleh informasi bahwa sosialisasi program melalui penyelenggara sesuai dengan hasil wawancara, bahwa :

"Dalam tahap sosialisasi program, secara langsung dilaksanakan di kantor kecamatan dengan mengundang kepala desa dari masing-masing desa untuk bisa hadir sedangkan pada tahap sosialisasi kemasyarakat dilaksanakan ditiap desa dan diberikan wewenang pada kepala desa masing-masing desa."

Menanggapi hal tersebut, pihak pemerintah desa Kalekube melalui kepala desa ketika diwawancarai mengemukakan bahwa :

"Setiap diadakan rapat koordinasi atau sosialisasi suatu program kami dari pihak pemerintah desa telah mengingatkan bahwa dalam tahap melakukan sosialisasi diharapkan agar dapat memberikan informasi mengenai pelaksanaan program dengan baik, karena pada pelaksanaannya berbeda dengan yang telah disosialisasikan sebelumnya."

Selanjutnya peneliti menemukan keluhan masyarakat mengenai sosialisasi program. Hal tersebut juga di ungkapkan oleh seorang warga masyarakat desa, yang mengatakan bahwa :

"Seharusnya pihak pelaksana program harus memberikan informasi yang jelas pada sosialisasi, terkadang apa yang disosialisasikan tidak sesuai dengan yang akan terjadi dilapangan, seperti contoh waktu pelaksanaan program dalam sosialisasi yaitu dilaksanakan 5 (lima) hari tetapi pada kenyataanya hanya 2 hari saja sehingga dalam melaksanakan pelayanan kepada masyarakat masih jauh dari harapan, karena waktu yang begitu singkat."

Menanggapi hal yang di keluhkan masyarakat dari pihak pelaksana program ketika di wawancarai, mengatakan bahwa :

"Kami dari pihak pelaksana juga menerima apa yang di keluhkan oleh masyarakat, karena apa yang kami laksanakan untuk kepentingan masyarakat itu sendiri. Anggaran yang belum mencukupi dan jumlah ASN yang terbatas yang masih menjadi kendala yang sangat mempengaruhi pihak pelaksana program yang terdiri dari SKPD terkait."

Hasil wawancara tersebut diperoleh informasi bahwa kemampuan penyelenggara program dalam melakukan sosialisasi masih kurang baik, banyak masyarakat yang keliru saat pelaksanaan program Me'Daseng ini sehingga perlu ditingkatkan lagi dalam melakukan sosialiasi agar dapat tersampaikan dengan baik kepada masyarakat pada umumnya dan pada sasaran program pada khususnya. 


\section{Tujuan Program}

Jika tidak ada penetapan tujuan, hasil yang ingin dicapai sangat sulit untuk diwujudkan. Tetapi jika tujuan ditetapkan maka pelaksanaan program hanya akan berorientasi pada tujuan yang telah ditetapkan sebelumnya. Untuk dapat mengetahui ukuran efektivitas dari suatu program dapat diketahui dengan melakukan perbandingan antara tujuan program dengn output program (Budiani, 2009). Hal tersebut dilihat dari beberapa indikator yang dikemukakan oleh Budiani yang salah satunya ialah tujuan program. Dalam indikator tersebut program kemudian dijabarkan lagi menjadi 2 (dua) yaitu: Program itu sendiri dan Upaya pencapaian.

Berdasarkan tujuan dari program Me'Daseng, yaitu dapat memberikan kesempatan kepada masyarakat untuk menyampaikan aspirasi dan permasalahan kepada pemerintah, membangun pemerintahan yang melayani serta peduli terhadap permasalahan dan aspirasi masyarakat, meningkatkan hubungan kerjasama antara pemerintah, masyarakat dan dunia usaha; dan memberikan kemudahan, kecepatan, keterjangkauan, keamanan, dan kenyamanan kepada masyarakat dalam mendapatkan pelayanan, serta mengembangkan nilai-nilai adat istiadat masyarakat Sangihe.

Jika dilihat dari sejauhmana kesesuaian antara hasil pelaksanaan program Me'Daseng dengan tujuannya, peneliti melakukan wawancara dengan camat Tabukan Utara selaku tim penyelenggara program Me'Daseng mengatakan bahwa :

"Menurut penilaian saya selaku tim penyelenggara program Me'Daseng di

Kecamatan Tabukan Utara, saya melihat sudah cukup sesuai antra hasil pelaksanaan program dengan tujuannya. Salah satu yang menjadi penilaian yaitu masyarakat begitu antusias ikut terlibat dalam mempersiapkan segala sesuatu yang dibutukan dalam pelaksanaan program Me'Daseng. Jika masyarakat senang berarti mereka pasti merasakan dampak positif dari program itu sendiri."

Hal tersebut di tanggapi oleh salah seorang pemerintah desa yang ada di Kecamatan Tabukan Utara, yaitu kepala desa Kalekube I yang mengatakan bahwa :

"Sebenarnya program ini tujuannya cukup baik, namun yang membuat program ini bisa dikatakan masih jauh dari tujuan yang di tentukan, karena masih ada SKPD yang tidak melakukan pelayanan dengan baik dan belum sesuai yang di sosialisasikan sebelumnya bahwa kata "Daseng" artinya menginap tetapi masa ada juga SKPD yang memilih pulang ke rumah."

Senada dengan pendapat dari kepala Desa Kalekube I, pemerintah Desa Beha melalui Kepala Desa Beha juga mengungkapkan bahwa :

"Saya menilai dalam tahap pelaksanaan program ini masih jauh dari tujuan program sebelumnya, masih ada SKPD yang belum melaksanakan tugasnya dengan baik, dan dalam kegitan meneyerap aspirasi masyarakat, belum ada yang dapat di realisasikan oleh pemerintah, seperti contoh yang menjadi keluhan masarakat pada kegitan forum "Me'Sombang" yang artinya Bertemu, yaitu jalan produksi pertanian yang ada di desa Beha dan yang ada di desa Kalekube dan Kalekube I, yaitu pemberdayaan masyrakat untuk para penambang pasir".

Permasalahan yang timbul adalah kemapuan SKPD dalam melaksanakan tugas dan fungsinya. Undang-Undang No 25 Tahun 2009 Tentang Pelayanan Publik merupakan undangundang yang mengatur tentang prinsip-prinsip pemerintahan yang baik yang merupakan efektivitas fungsi-fungsi pemerintahan. Pelayanan publik yang efektif dilakukan oleh pemerintah dapat memperkuat demokrasi dan hak asasi manusia,99 mengurangi kemiskinan, kemakmuran ekonomi, serta bijak dalam memanfaatkan sumber daya alam, memperdalam kepercayaan pada pemerintah.

Peneliti disini juga menemukan keluhan dari masyarakat terkait dengan pelayanan yang di berikan oleh petugas, seperti yang disampaikan berikut :

"Petugas pelayanan yang terdiri dari SKPD saya rasa sangat lamban dalam melakukan pelayanan dan dalam waktu yang sangat singkat tidak semua masyarakat di 1 (Satu) kecamatan dapat terlayani dengan baik sedangkan dari masyarakat sendiri mengharapkan pelayanan yang baik dari petugas pelayanan, karena tiap masyarakat mempunyai pemasalahan yang bebedabeda mulai dari kesehatan, pembuatan e$K T P$, pembuatan perijinan dan lain 
sebagainya hal ini mengindikasikan bahwa pelayanan yang di berikan petugas pelayanan dapat mempengaruhi tujuan program yang telah tetapkan sebelumnya."

Dari hasil wawancara tersebut ditemukan bahwa masih belum maksimalnya pelayanan yang diberikan oleh SKPD terkait sehingga masih belum sesuai dengan tujuan dari program Me'Daseng yang telah ditetapkan dan yang telah disosialisasikan dimasyarakat.

Sudah menjadi suatu kewajiban dari pemerintah untuk melayani setiap warga masyarakat atau penduduk untuk dapat memenuhi hak dan kewajiban serta kebutuhan dasar dalam pelayanan publik yang menjadi amanat Undang-Undang Dasar Tahun 1945, membangun kepercayaan masyarakat terhadap pelayanan publik yang dilakukan oleh penyelenggara program pelayanan merupakan suatu hal yang harus dilakukan seiring dengan harapan dan juga tuntutan dari masyarakat. Peningkatan pelayanan publik ini yang menjadi fokus utama dari pemerintah Kabupaten Kepulauan Sangihe terlebih khusus yang ada di Kecamatan Tabukan Utara.

\section{Pemantauan Program}

Salah satu indikator yang yang dikemukakan oleh Budiani yaitu pemantauan. Pemantauan merupakan kegiatan yang dilakukan setelah dilaksanakannya suatu program kegiatan yang dapat dikatakan sebagai bentuk perhatian dari penyelenggara terhadap peserta program. Dilakukannya suatu pemantauan yaitu untuk mendapatkan informasi tentang program apakah memberikan dampak yang positif dan berkelanjutan bagi peserta setelah mengikuti program. Pemantauan ini sangat penting dilakukan agar dapat diidentifikasi jika dalam pelaksanaan ada yang berbeda dengan yang sudah ditetapkan sehingga dapat diketahui kekurangan dari pelaksanaan, kemudian dicarikan suatu solusi untuk mengatasi permasalahan tersebut. Seperti yang dikemukakan oleh Calyton dan Perty dalam Soekartawi (1995) pemantauan merupakan suatu proses mengukur, mencatat, mengumpulkan, memproses, sera mengkomunikasikan informasi untuk membantu pengambilan keputusan manajemen program
Pematauan dilakukan oleh para petugas pelaksana program Me'Daseng yang ada di Kecamatan Tabukan Utara, hal ini diperjelas setelah peneliti melakukan wawancara kepada Bupati Kabupaten Kepulauan Sangihe yang mengatakan :

"Setelah melakukan pemberdayaan kepada masyarakat dengan memberikan pelayanan yang sesuai dengan kebutuhan masyarakat, kami selaku pelaksana program Me'Daseng meyerahkan ke tiap kecamatan dalam melakukan monitoring bersama dengan panitia pelaksana program untuk mengetahui dampak yang di rasakan masyarakat setelah dilaksanakanya program Me'Daseng dan menurut saya cukup berdampak positif ke masyarakat penerima pelayanan baik dalam pembuatan kesehatan, e-KTP, ijin usaha, dan lain sebagainya."

Untuk lebih lanjut, peneliti melakukan wawancara kepada camat Tabukan Utara selaku ketua panitia penyelenggara program Me'Daseng yang ada di Tabukan Utara, mengatakan bahwa :

"Iya kami selaku panitia penyelenggara bersama dengan panitia pelaksana lainya melakukan pemantauan atau monitoring kepada peserta program. Kami melalui tiap kepala desa selaku tim penyelenggara langsung mencari informasi apakah masyarakat sendiri bisa merasakan dampak positif dari pelaksanaan program Me'Daseng ini dan tidak lagi menempuh jarak yang cukup jauh dalam segala hal yang bekaitan dengan pelayanan."

Dari penjelasan sebelumnya, peneliti melakukan penelusuran lebih lanjut mengenai masyarakat penerima pelayanan dari SKPD terkait, penulis mendapat informasi bahwa tidak semua masyarakat medapatkan pelayanan yang maksimal, bahkan masih ada masyarakat yang belum medapatkan pelayanan sama sekali. Hal ini juga langsung di kemukakan oleh kepala desa Kalekube yang sebelumnya menjadi tempat pelaksanaan program Me'Daseng, kepada peneliti Kepala Desa mengatakan bahwa :

"Banyak masyarakat yang mengeluh dalam pelaksanaan program ini karena masih banyak SKPD yang belum begitu baik dalam melayani masyarakat, bahkan ada masyarakat yang mengatakan bahwa program Me'Daseng ini hanya buangbuang dana saja, belum ada dampak yang 
begitu efektif yang di rasakan oleh masyarakat, dalam kurun waktu 2 hari, SKPD pasti tidak dapat melayani masyarakat yang ada di Tabukan Utara yang memiliki keperluan yang berbedabeda".

Menanggapi hal tersebut, camat Tabukan Utara kepada peneliti, mengemukakan bahwa :

"Kami dari panitia pelaksana kecamatan sudah berusaha semaksimal mungkin untuk kepentingan masyarakat, ini menjadi bahan masukan untuk kami selaku panitia pelaksana program Me’Daseng di Kecamatan Tabukan Utara”.

Dari hasil wawancara, dapat disimpulkan bahwa pemantauan setelah program Me'Daseng dilaksanakan di Kecamatan Tabukan Utara belum efektif, dengan melihat apa yang terjadi di masyarakat dan masih banyaknya keluhan masyarakat mengenai pelaksanaan program Me'Daseng yang belum begitu baik dalam memberikan pelayanan ke masyarakat yang berkaitan dengan pelayanan publik.

Ketepatan sasaran dari program yang dibentuk oleh pemerintah dilihat dari apakah peserta program tersebut tepat dengan sasarn yang sudah ditetapkan sebelumnya. Pembentukan suatu yang disebut dengan kebijakan dilihat dari kebutuhan masyarakat. Masyarakat atau peserta yang terlibat diharapakan dapat merasakan dan menikmati pelayaan yang diberikan oleh tim penyelenggara. Sehingga dapat dikatakan sebagai penjawab kebutuhan dari masyarakat. Program Me'Daseng dibuat untuk mendekatkan pelayanan kepada masyarakat sehingga masyarakat tidak lagi harus menempu jarak yang cukup jauh dalam hal yang bersangkutan dengan urusan yang menyangkut pelayanan publik seperti sosialisasi, penyuluhan, pendataan, pelayanan administrasi pelayanan perijinan, pemeriksaan kesehatan, dan pengobatan gratis.

Sebagaimana yang dikatakan oleh Bupati Kabupaten Kepulauan Sangihe bahwa program Me'Daseng pada intinya yaitu medekatkan pemerintah dengan masyarakat, pemerintah turun lansung dalam melaksanakan pelayanan pada masyarakat, melihat kondisi aktual dilapangan dan mendengar masukan-masukan dari masyarakat, memangkas jarak, birokrasi serta biaya. Sehingga dapat mendatangkan manfaat yang baik di masyarakat. Karena tujuan dari program Me'Daseng yaitu untuk mendatangkan manfaat kepada masyarakat sekitar. Pihak-pihak yang terlibat dalam program Me'Daseng di Kecamatan Tabukan Utara yaitu SKPD yang terlibat dalam pelaksanaan program yang dilaksanakan di seluruh wilayah Kabupaten Kepulauan Sangihe, maka kegiatan yang dilakukan dalam Program Me'Daseng perlu ditinjau kembali karena masih tidak tepat sasaran.

Forum Me'Sombang dan pemeriksaan kesehatan serta pengobatan gratis merupakan yang paling ditunggu oleh masyarakat yang ada di Kecamatan Tabukan Utara, karena dalam forum Me'Sombang masyarakat dapat menyampaikan langsung keluhan-keluhan mereka atau kendala-kendala yang terjadi dalam kehidupan bermasyarakat. Sedangkan pada pemeriksaan kesahatan dan pengobatan gratis masyarakat sangat antusias karena jarak yang cukup jauh ke rumah sakit dan yang menjadi kendala di sebagian besar masyarakat Tabukan Utara yaitu masalah biaya.

Sosialisasi program, yaitu kemampuan penyelenggara program untuk melakukan sosialisasi sebaik mungkin agar informasi tentang pelaksanaan program tersampaikan ke masyarakat atau peserta program. Sosialisasi merupakan suatu bentuk komunikasi dari pelaksana program Me'Daseng yaitu pemerintah Kabupaten Kepulauan Sangihe beserta SKPD terkait dalam menyampaikan informasi tentang pelaksanaan program Me'Daseng kepada masyarakat khususnya yang ada di Kecamatan Tabukan Utara untuk bisa melibatkan diri pada penyelenggaraan program baik yang menjadi peserta atau juga membantu pelaksanaan dari program itu sendiri.

SKPD mempunyai fungsi sebagai komunikasi yaitu memberikan penjelasan mengenai program Me'Daseng yang menjadi target dari suatu program kebijakan. Komunikasi yang dilakukan oleh SKPD yaitu dengan cara tatap muka langsung dan bermedia seperti melalui radio. Dalam menjalankan fungsi tersebut dilakukan sosialisasi di kantor kecamatan dengan mengundang kepala-kepala desa yang berada di wilayah Kecamatan Tabukan Utara. Sosialisasi atau upaya pemerintah Kabupaten Kepulauan Sangihe untuk menyebarkan informasi mengenai Me'Daseng juga dilakukan dengan media yaitu melalui radio, dilakukan pemerintah agar masyarakat dapat mendengar langsung yang menjadi pokok dalam program Me'Daseng mulai dari tempat, waktu pelaksanaan dan kegitan yang 
dilakukan baik berupa Sosialisasi, Penyuluhan, Pendataan, Pelayanan Administrasi Pelayanan Perijinan, Pemeriksaan Kesehatan dan Pengobatan gratis.

Dari hasil wawancara serta observasi yang dilakukan dapat disimpulkan bahwa SKPD yang juga termasuk dalam penyelenggara program belum mampu untuk mensosialisasikan program kepada masyarakat yang ada di Kecamatan Tabukan Utara sehingga masyarakat masih banyak yang tidak melibatkan diri dalam pelaksanaan program Me'Daseng, mengingat sosialisasi merupakan langkah awal yang sangat penting untuk dilakukan sebelum dilaksanakannya suatu Perogram kegiatan.

Tujuan bagaiamana kesesuaian antara tujuan program yang telah ditetapkan dengan hasil pelaksanaan Me'Daseng menjadi hasil dari suatu kebijakan yang diharuskan dapat memenuhi apa yang menjadi tujuan dari program Me'Daseng itu sendiri. Program dapat dikatakan efektif bila hasil dari program tersebut tepat sasaran. Tujuan dari program Me'Daseng yaitu:

a. Memberikan kesempatan kepada masyarakat untuk menyampaikan aspirasi dan permasalahan kepada pemerintah.

Usulan, keinginan atau kehendak disertai harapan yang hendak agar bisa tercapai, aspirasi disini pun hanya akan menjadi sebatas usulan dan harapan masyarakat yang tidak akan terwujud jika dari pemerintah sendiri tidak mengambil tindakan untuk mewujudkanya. Dalam penyelenggaraan program Me'Daseng khususnya di Kecamatan Tabukan Utara, banyak permasalahan yang dikeluhkan oleh masyarakat, melalui forum Me'Sombang yang artinya "Bertemu" masyarakat diberikan kesempatan untuk bertatapan langsung dengan pemerintah daerah dan yang menjadi keluhan dari masyarakat yang ada di Kecamatan Tabukan Utara seperti pemberdayaan untuk para penambang pasir yang berada di desa Kalekube, Kalekube I, Mala, dan Kalasuge selanjutnya juga ada yang dari masyarakat yang mengeluhkan ketersediaan air bersih, jalan produksi pertanian, tanggul untuk mengantisipasi meluapnya banjir dan air pasang. Berdasarkan data yang ada peneliti melihat program Me'Daseng masih belum berhasil hal ini dibuktikan dengan belum terwujudnya salah satu yang dikeluhkan oleh masyarakat. Sehingga dapat disimpulkan bahwa dalam forum ini pemerintah hanya sebatas mendengar, belum ada satu tindakan pemerintah untuk mewujudkan apa yang telah menjadi keluhan dan harapan dari masyarakat.

b. Membangun pemerintahan yang melayani serta peduli terhadap permasalahan dan aspirasi masyarakat.

Dalam situasi seperti sekarang ini, tentunya menjadi tugas pemerintah untuk mewujudkan suatu pelayanan, dalam hal ini pemerintah adalah lembaga yang memproduksi, mendistribusikan, atau memberikan alat pemenuhan kebutuhan berupa pelayanan publik. Bupati Kabupaten Kepulauan Sangihe membuat program Me'Daseng sebagai komitmen untuk melaksanakan pelayanan kepada masyarakat semaksimal mungkin, serta dalam rangka perbaikan tata pemerintahan yang mendorong pemahaman bahwa betapa pentingnya suatu kualitas pelayanan publik serta perbaikan mutu pelayanan publik maka yang dimaksud harus mampu dijabarkan dalam pelaksanaan tugas pelayanan publik sebagaimana tugas pokok Pemerintah Daerah. Pelayanan kepada masyarakat merupakan suatu bentuk interaksi antara penyedia pelayanan dan penerima pelayanan dengan kata lain dalam hubungan pemerintah terkandung makna adanya organisasi yang memerintah dan masyarakat yang diperintah. Pemerintahan yang modern pada hakikatnya adalah pelayanan kepada masyarakat, ini yang menjadi tujuan utama dari pemerintah Kabupaten Kepulauan Sangihe sehingga dibentuknya program Me'Daseng. Pemerintah tidaklah diadakan untuk melayani diri sendiri, melainkan untuk melakukan pelayanan kepada masyarakat, menciptakan kondisi yang memungkinkan setiap anggota masyarakat mengembangkan kemampuan dan kreatifitasnya demi mencapai kemajuan bersama. meningkatkan hubungan kerjasama antara pemerintah, masyarakat dan dunia usaha. Namun dalam pelaksanaan program tersebut SKPD terkait masih belum mampu memberikan pelayanan terbaik kepada masyarakat yang ada di Kecamatan Tabukan Utara, banyak dari masyarakat yang mengeluhkan tentang singkatnya waktu dan minimnya ASN yang memberikan pelayanan. Maka peneliti dapat menyimpulkan bahwa program Me'Daseng masih belum efektif, belum sesuai yang direncanakan pemerintah sebelumnya dan yang di harapkan masyarakat.

c. Memberikan kemudahan, kecepatan, 
keterjangkauan, keamanan, dan kenyamanan kepada masyarakat dalam mendapatkan pelayanan.

Menjalankan fungsi sebagai pemerintah maka pelayanan publik tidak hanya semata bersifat "Profit oriented" melainkan lebih berorientasi sosial yaitu penguatan dan pemberdayaan masyarakat.

Seiring peningkatan kehidupan manusia, tuntutan akan pelayanan publik juga semakin meningkat. Masyarakat bukan hanya mengharapkan terpenuhinya kebutuhan pelayanan yang baik, tetapi lebih dari itu, masyarakat mulai mempertanyakan penjaminan ketersediaan dan kualitas pelayanan publik yang diberikan oleh pemerintah. Dengan adanya program Me'Daseng tersebut di harapkan mampu mengatasi masalah pelayanan yang terjadi di masyarakat khususnya yang ada di Tabukan Utara serta menimbang tuntutan masyarakat terhadap proses, jarak, waktu, dan biaya yang dikeluarkan untuk memperoleh dan atau menjangkau pelayanan. Jadi dapat diambil kesimpulan bahwa program Me'Deseng ini sebagai program yang mengedepankan kualitas pelayanan yang baik dan menguntungkan kepada masyarakat.

d. Mengembangkan nilai-nilai, adat istiadat masyarakat Sangihe.

Untuk menjaga agar nilai, adat-istiadat dan kebiasaan yang telah tumbuh, hidup dan berkembang dalam praksis kultural, tetap lestari dan tidak hilang di Sangihe. Nilai, tradisi, adat istiadat, budaya yang tumbuh pada suatu masyarakat pada dasarnya juga menjadi asset atau modal sosial yang penting dalam rangka memberdayakan (empowering) masyarakat demi mewujudkan kualitas hidup dan kesejahteraan. Disamping itu, pelestarian tradisi penting dilakukan untuk mengeliminir ekses modernisasi yang menghancurkan ikatan nilai tradisi seperti kekeluargaan, gotong-royong, nilai-nilai keagamaan, adat-kebiasaan lokal, maupun pranata budaya yang sebenarnya telah berurat dan berakar dalam formasi kehidupan sosial. Program Me'Daseng sendiri mempunyai makna dalam bahasa sangihe yaitu menetap dipondok atau menginap kecil yang biasanya dibangun dikebun atau dipinggiran pantai untuk dapat menyelesaikan sebuah pekerjaan, ini sudah menjadi kebiasaan masyarakat yang ada, sehingga dalam program ini SKPD di instruksikan untuk menginap sesuai dengan nilai yang terkandung dalam kata Me'Daseng. Dalam pelaksanaan program ini juga di haruskan mengkonsumsi makanan khas daerah sangihe seperti sagu, pisang, umbi-umbian dan lain sebagainya

Sedangkan pengembangan diarahkan guna merevitalisasi nilai, norma, tradisi, budaya dan kearifan lokal agar sejalan dengan perubahan zaman sekaligus kepentingan praktis bagi peningkatan kemajuan, kesejahteraan, dan kemandirian masyarakat Kabepaten Kepulauan Sangihe khususnya yang ada di kecamatan Tabukan Utara. Sehigga dengan adanya program Me'Daseng ini diharapkan masyarakat mampu menjaga, melestarikan dan mengembangkan nilanilai adat-istiadat yang ada di Kabupaten Kepulauan Sangihe.

Pemantauan program kegiatan yang dilakukan setelah dilaksanakanya program sebagai bentuk perhatian kepada peserta program atau masyarakat. Untuk menjadikan program Me'Daseng efektif penerapannya di Kecamatan Tabukan Utara, Kabupaten Kepulauan Sangihe. Jika melihat melalui indikator pemantauan program, maka usaha yang dilakukan untuk melakukan pemantauan oleh penyelenggara yaitu dengan melakukan komunikasi langsung ke peserta program. Pemantauan ke peserta program dilakukan melalui media telekomunikasi sarta pemantauan secara berkala ke peserta program. Maanfaat dilakukannya pemantauan yaitu sebagai bahan evaluasi program Me'Daseng dan sebagai bentuk perhatian dari penyelenggara program kepada masyarakat atau peserta program. Berdasarkan data yang diperoleh pada saat penelitian maka dapat disimpulkan bahwa dalam pemantauan program ini, petugas pemantau program sudah melakukan monitoring dengan cukup baik, pemantauan dilakukan oleh petugas setelah dilaksanakannya program, sehingga diharapkan permasalahan-permasalahan yang terjadi dilapangan atau kendala-kendala dalam pelaksanaan dapat di evaluasi dan ditanggulangi agar tidak menganggu jalanya program.

\section{Faktor-Faktor Penghambat Pelaksanaan Program Me'Daseng}

Terdapat paling kurang empat faktor penghambat dalam pelaksanaan program Me'Daseng di Kecamatan Tabukan Utara yang ditemukan dalam penelitian ini, yaitu : kemampuan penyelenggara program, karakter birokrat dari segi empati, keterbatasan jumlah 
Aparatur Sipil Negara, dan kondisi kerja. Keempat faktor penghambat dapat dijelaskan secara terinci sebagai berikut:

a. Kemampuan

Kemampuan merupakan kualitas yang dimiliki oleh penyelenggara dalam melakukan pelayanan kepada masyarakat atau peserta program. Hal tersebut dilihat bagaimana pengetahuan petugas, ketrampilan petugas, kecakapan petugas, tingkat pengalaman dalam bekerja, kesungguhan dalam melaksanakan tugas dan lain sebagainya. Kemampuan dalam memberikan layanan pada program Me'Daseng masih kurang baik. Berdasarkan data yang didapat oleh peneliti kemampuan petugas dalam memberikan pelayanan masih kurang cepat dan tidak sungguh-sungguh dalam melaksanakan tugas.

b. Karakter Birokrat Dari Segi Empati

Empati merupakan kesediaan dari petugas untuk lebih peduli dalam memberikan perhatian secara pribadi kepada masyarakat atau peserta program. Seperti, misalnya petugas harus mencoba menempatkan dirinya sebagai pihak yang melayani. Seandainya ada masyarakat yang tidak puas dengan pelayanan yang diberikan harus dicarikan jalan keluar untuk dapat mencapai kesepakatan bersama. Empati dijabarkan menjadi beberapa indikator yaitu: usaha untuk meberikan layanan terbaik, keramahan petugas dalam memberikan pelayanan, keadilan dalam pelayanan dan kesediaan bekerja lama.

c. Keterbatasan jumlah Aparatur Sipil Negara

Jumlah ASN yang kurang juga menjadi penghambat dan sangat mempengaruhi pelaksanaan program Me'Daseng, hal tersebut di karenakan tidak semua ASN tiap SKPD turun langsung dalam pelaksanaan program tersebut, karena harus berbagi tugas di kantor dan tempat dilaksanakannya program Me'Daseng.

d. Kondisi Kerja

Kondisi kerja yang dimaksud disini ialah suasana kerja yang dapat mendorong petugas pelakasanaan program Me'Daseng untuk mengaktualisasikan potensinya dan menampilkan pekerjaannya secara baik. Kondisi kerja yang dapat menunjang pelaksanaan pekerjaan yang dilakukan oleh para aparatur apabila suasana kerja yang kooperatif dan kolaboratif, fasilitas kerja yang memadai, tanggung jawab setiap aparat diciptakan. Akan tetapi kondisi kerja dalam pelaksanaan program Me'Daseng kurang begitu disiplin dalam mematuhi waktu-waktu kerja, tidak terampilnya dan minimnya dedikasi dan komitmen terhadap tugas dan tanggung jawabnya. Hal tersebut merupakan refleksi dari suasana kerja yang tidak kooperatif, kolaboratif, kurangnya tanggung jawab masing-masing aparat, juga karena minimnya fasilitas kerja yang ada pada saat pelaksanaan program Me'Daseng tersebut.

e. Anggaran

Anggaran merupakan suatu rencana yang disusun secara sistematis dalam bentuk angka atau nominal dan dinyatakan dalam unit moneter, meliputi seluruh aktivitas atau kegiatan yang dilakukan oleh suatu badan atau perusahaan untuk jangka waktu atau periode tertentu di masa yang akan datang. Minimnya anggaran dalam pelaksanaan program Me'Daseng, sehingga dalam pelaksanaannya masih di bebankan kepada tim penyelenggara atau tiap SKPD yang menjadi petugas penyelenggara program dan dari dana alokasi umum (DAU) yang bersumber dari APBN.

\section{KESIMPULAN DAN SARAN}

\section{Kesimpulan}

Hasil penelitian menunjukkan bahwa

1. Program Me'Daseng di Kecamatan Tabukan Utara belum sepenuhnya efektif, dari segi ketepatan sasaran, masyarakat masih kurang terlibat disaat dilaksanakannya program Me'Daseng.

2. Sosialsiasi program Me'Daseng sudah dilakukan belum begitu baik terutama sosialisasi langsung yang dilakukan di masyarakat yang ada di Kecamatan Tabukan Utara.

3. Efektivitas program Me'Daseng di Kecamatan Tabukan Utara jika dilihat dari tujuan program Me'Daseng dan dibandingkan dengan hasil yang dicapai belum begitu efektif. 
4. Pemerintah sudah berupaya melakukan perbaiakan dalam penyelenggaraan program Me'Daseng, sebagai upaya untuk memperhatikan masyarakat penerima pelayanan dari program Me'Daseng, tetapi dampak yang dirasakan oleh masyarakat masih belum sesuai yang di harapakan sebelumnya.

\section{Saran}

1. Pelayanan kepada masyarakat merupakan suatu bentuk interaksi antara penyedia layanan dan penerima layanan. Program Me'Daseng harus dapat memberikan pelayanan yang terbaik untuk masyarakat khususnya masyarakat Tabukan Utara karena menyangkut kepentingan masyarakat pada umumnya.

2. Dalam melakukan sosialisasi diharapkan peningkatan penyampaian tentang program Me'Daseng lebih jelas dan sesuai dengan yang dilaksanakan di lapangan, serta pemanfaatan media seperti radio juga perlu di tingkatkan mengingat radio merupakan salah satu media yang paling banyak digunakan oleh masyarakat yang ada di Kabupaten Kepulauan Sangihe terlebih khusus masyarakat Tabukan Utara.

3. Petugas pelaksana program diharapakan harus lebih optimal lagi dalam melaksanakan tugas dan tanggung jawab. Kualitas pelayanan ditentukan oleh pemberi pelayanan, pelayanan yang baik kepada masyarakat merupakan hal yang di utamakan dalam pelaksanaan program Me'Daseng.

4. Pemerintah perlu melakukan perbaikan disetiap kendala atau masalah yang di hadapi pada pelaksanaan program. Dan pemerintah harus lebih baik lagi dalam memfasilitasi pelaksanaan program Me'Daseng, agar masyarakat penerima program merasa terbantu dengan adanya program Me'Daseng ini.

\section{DAFTAR PUSTAKA}

Budiani, Ni Wayan. 2009. Efektivitas Program Penanggulangan Karang Taruna "Eka Taruna Bhakti" Desa Sumerta Kelod Kecamatan Denpasar Timur Kota Denpasar. Jurnal Ekonomi dan Sosial Input, 2.
Pemerintah Kabupaten Kepulauan Sangihe. 2007. Surat Keputusan Bupati Kabupaten Kepulauan Sangihe Nomor 172.1/710/Tahun 2017 Tentang Penetapan Wilayah/ Lokasi Pelaksanaan Program Me'Daseng

Pemerintah Republik Indonesia. 2009. Undangundang Nomor 25 Tahun 2009 tentang Pelayanan Publik 